\title{
Correction to: The sbGnRH-GTH system in the female short mackerel, Rastrelliger brachysoma (Bleeker, 1851), during breeding season: implications for low gamete production in captive broodstock
}

\author{
Sinlapachai Senarat • Jes Kettratad • Niwat Kangwanrangsan • \\ Wannee Jiraungkoorskul • Masafumi Amano - Akio Shimizu • \\ F. Gerald Plumley • Sasipong Tipdomrongpong
}

Published online: 5 September 2018

(C) Springer Nature B.V. 2018

Correction to: Fish Physiology and Biochemistry https://doi.org/10.1007/s10695-018-0509-x

The published online version of this article contained outdated Figs. 1 to 7 . The original article has been corrected.

The online version of the original article can be found at https://doi.org/10.1007/s10695-018-0509-x

S. Senarat $\cdot$ J. Kettratad $(\bowtie) \cdot$ F. G. Plumley

Department of Marine Science, Faculty of Science, Chulalongkorn University, Bangkok 10330, Thailand

e-mail: Jes.K@chula.ac.th

N. Kangwanrangsan · W. Jiraungkoorskul

Department of Pathobiology, Faculty of Science, Mahidol

University, Bangkok 10400, Thailand

M. Amano

School of Marine Biosciences, Kitasato University, Sagamihara,

Kanagawa 252-0373, Japan

\section{A. Shimizu}

National Research Institute of Fisheries Science, Fukuura 2-12-4,

Kanazawa, Yokohama 236-8648, Japan

\section{S. Tipdomrongpong}

Samut Songkhram Marine Fisheries Research and Development Station, Department of Fisheries, Samut Songkhram 75000,

Thailand 